\title{
NEW RECORDS AND RARE SPECIES OF PYRENOCARPOUS LICHEN-FORMING FUNGI FROM BULGARIA
}

\author{
Veselin V. ShIVAROV ${ }^{1 *}$ and László LőKö ${ }^{2}$ \\ ${ }^{1}$ Institute of Biodiversity and Ecosystem Research, Bulgarian Academy of Sciences, \\ 2 Gagarin St., BG-1113 Sofia, Bulgaria; *v.shivarov@abv.bg \\ ${ }^{2}$ Department of Botany, Hungarian Natural History Museum, \\ H-1476 Budapest, Pf. 222, Hungary
}

Shivarov, V. V. \& Lőkös, L. (2015): New records and rare species of pyrenocarpous lichen-forming fungi from Bulgaria. - Studia bot. hung. 46(2): 111-118.

\begin{abstract}
Five pyrenocarpous lichen species, Polyblastia cupularis, P. dermatodes, Porina lectissima, Thelidium pertusatii, and Verrucaria umbrinula, are reported for the first time from Bulgaria. All provided descriptions are based on the examined specimens deposited in BP. Description and illustrations of $V$. bulgarica based on the type material are also provided. T. pertusatii and V. bulgari$c a$ known only from few localities worldwide are regarded as rare species. Worldwide distribution, ecological preferences and comments are given for all examined species.
\end{abstract}

Key words: lichen-forming fungi, Porinaceae, Verrucariaceae

\section{INTRODUCTION}

One of the largest collections of lichen-forming fungi from Bulgaria is deposited in the Hungarian Natural History Museum, Budapest (BP). Most of the specimens were collected by the prominent Hungarian lichenologist, Dr Ödön Szatala. He visited Bulgaria first in 1929 and made several field trips to Bulgarian mountains and to the Bulgarian Black Sea coast. The collected specimens were revised and published in two papers with more than 400 taxa, of which 5 species and 7 infraspecific taxa were new for science (Szatala 1929, 1930). In 1954 he travelled to Bulgaria again with the aim to collect specimens for a monographic work on Bulgarian lichen-forming mycota. He collected lichen specimens from regions previously not studied by him, like the Pirin Mts, where together with the Bulgarian lichenologist Bozhana Zhelezova they visited the high mountain sites. Unfortunately, he died four years later (in 1958), and several specimens from Bulgaria are still not determined. Further unidentified Bulgarian material is deposited in BP from a smaller, old collection of Atanas Popnikolov and from recent collections of the second author. 
The old specimens can provide valuable information not only about the distribution and the variety of lichenized fungi, but can give data also on the changes in the environment during several decades. The change in temperature due to global warming might limit the distribution of some amphibious lichens in the genera Thelidium and Verrucaria (THÜs and SCHUlTz 2008).

The first catalogue of lichen-forming fungi of Bulgaria published by MAYRHOFER et al. (2005), was completed with 24 further records of pyrenocarpous lichens (OTTE 2005, VondRÁ K 2006, KRZEWICKA et al. 2007, SPIER et al. 2008, Shivarov 2013, Shivarov and Stoy kov 2013). In this article five additional species are reported for the first time from Bulgaria. Thelidium pertusatii and Verrucaria bulgarica are considered as rare lichen-forming fungi based on their worldwide distribution and recent intensive study of this group in Bulgaria.

\section{MATERIAL AND METHODS}

Eighty-two specimens of pyrenocarpous lichens deposited in BP have been revised, of which seven are presented in this study as rare species or new records for Bulgaria. The measurements and illustrations were made in water except for the measurements of the ascospores in the members of genus Polyblastia, which were made in $10 \% \mathrm{KOH}$. Macrophotographs were taken by means of a Windaus Labortechnik D-38678 dissecting microscope equipped with a Canon PowerShot A630 digital camera. Microphotographs were made under Boeco BM-180/T/SP binocular microscope and digital camera HP Photosmart M517. The type material of Verrucaria bulgarica was photographed with digital camera Olympus E-450 mounted on Olympus BX-50 and Olympus SZX-9 microscopes.

\section{RESULTS AND DISCUSSION}

\section{Polyblastia cupularis A. Massal.}

Thallus endolithic to semi-endolithic, continuous, without cracks, whitish to pale grey-brown. Perithecia $300-450 \mu \mathrm{m}$ in diameter, superficial to one-third immersed, the base covered by hyphae and fragments of the substratum, giving dusted appearance. Involucrellum 50-70 $\mu \mathrm{m}$ thick, well developed. Exciple pale brown or dark brown. Asci 8-spored. Ascospores 31-42 × 18-29 $\mu \mathrm{m}$, ellipsoid to broadly ellipsoid, muriform, colourless. Conidiomata not observed.

Specimen examined: Bulgaria, Pirin Mts, on calcareous rock, alt. 2500 m, leg. A. Popnikolov, (date not indicated, probably 1923-1931) (BP 255).

Ecology and distribution: on calcareous rocks in exposed terrestrial habitats; widespread in alpine environment, rare in lower elevations. Known from Europe, 
Asia and North America (Swinscow 1971, Wirth 1995, Urbanavichus and ANDreEv 2010, OrAnge 2013).

Taxonomic notes: according to SAVić and TIBELL (2012), the specimens of Polyblastia cupularis in North Europe are incorrectly determined, and refer to P. fuscoargillacea Anzi, and other related species. P. fuscoargillacea is widely distributed also on calcareous rocks, but differs in having areolate thallus and smaller ascospores.

The examined specimen contains also Thelidium incavatum (Nyl.) Mudd, an endolithic lichen species typical for exposed calcareous rocks at high altitude in the Pirin Mts.

Polyblastia dermatodes A. Massal.

Thallus endolithic, pale grey or brownish. Perithecia completely immersed in the substratum. Involucrellum absent. Exciple pigmented throughout. Asci $130-150 \times 40 \mu \mathrm{m}, 8$-spored, clavate. Ascospores 45-60 × 14-19 $\mu \mathrm{m}$, narrowly ellipsoid, colourless, submuriform with 3-6 transverse septa and 1-3 longitudinal septa. Conidiomata not observed.

Specimen examined: Bulgaria, Pirin Mts, on calcareous rock, alt. $1500 \mathrm{~m}$, leg. A. Popnikolov, (date not indicated, probably 1923-1931) (BP 258).

Ecology and distribution: on calcareous rocks in mountains. Known from Europe and Australia (Zschacke 1933, Swinscow 1971, Orange 2013).

Taxonomic notes: Polyblastia dermatodes differs from Thelidium incavatum only with more transverse and longitudinal septa in ascospores, but this character can be variable even within a single fruit-body. Ascospores of all the examined Bulgarian specimens of $T$. incavatum have three transverse or very rarely one longitudinal septa.

A recent study based on molecular phylogeny revealed that $T$. incavatum and members of genus Polyblastia with submuriform ascospores, endolithic thallus and immersed perithecia were closely related and formed a group together with members of genera Staurothele and Verrucaria (SAVIć et al. 2008). The placement of $P$. dermatodes in this group was suggested by SAVić and TIBELL (2012). This taxon must be excluded from Polyblastia when the delimitations of the group become clear.

Porina lectissima (Fr.) Zahlbr.

Thallus epilithic, continuous or with fine cracks, ochre or pale brownish grey. Photobiont Trentepohlia. Perithecia 340-500 $\mu \mathrm{m}$ in diameter, semi-immersed, red-brown (intensely coloured when wet) to black at the apex. Involucrellum well-developed, orange to orange-red near the ostiole, $\mathrm{K}+$ intense orange-red 
throughout. Exciple colourless to pale orange in the upper half. Asci 8-spored, uniformly thin-walled, functionally unitunicate, with apical ring. Ascospores 20-26 × 4-6 $\mu \mathrm{m}$, narrowly ellipsoid, 3-septate, colourless. Pycnidia 140-280 $\mu \mathrm{m}$ in diameter, orange; apex pale orange to whitish. Conidia 2.5-3.5 $\times 1 \mu \mathrm{m}$.

Specimen examined: Bulgaria, Balkan Range, Berkovitsa town, upper parts of Haydushki Vodopadi waterfalls, along the red tourist route, on siliceous rock, $43.19919^{\circ} \mathrm{N}, 23.04997^{\circ} \mathrm{E}$, alt. $950 \mathrm{~m}$; leg. L. Lőkös, 28.06.2006 (BP 96052).

Ecology and distribution: on siliceous rocks in shady humid places, tolerating limited periods of submersion in upland watercourses. Known from Europe, Asia and North America (Thüs and SChultz 2008, URbanaVichus and ANDREEV 2010, ORANGE 2013).

Taxonomic notes: easily recognised by the large red-brown perithecia and 3 -septate ascospores of moderate length and width.

\section{Thelidium pertusatii (Garov.) Jatta}

(Figs 1-3)

Thallus epilithic, thin or up to $130 \mu \mathrm{m}$ thick, brown to grey-brown, continuous or with fine cracks; upper layer undefined, with brownish pigment in uppermost layer. Prothallus present as thin black line. Perithecia $400-620 \mu \mathrm{m}$ in diameter, prominent, black, not covered by thallus; apex flat or usually concave. Involucrellum well-developed, 90-180 $\mu \mathrm{m}$ thick, black, appressed to exciple and extending to the base. Exciple $230-350 \mu \mathrm{m}$ in diameter, black or pale brown, $\mathrm{K}+$ olivaceous; ratio of involucrellum thickness to exciple diameter 0.39-0.56. Periphyses 36-45 $\mu \mathrm{m}$ long. Asci 70-100 × 25-40 $\mu \mathrm{m}$, 8-spored. Ascospores 28-37 $(-39) \times 12-18 \mu \mathrm{m}$, ellipsoid, uniseptate, colourless, with perispore. Conidiomata not observed.

Specimen examined: Bulgaria, Pirin Mts, above Demyanitsa Hut, Yulen Reserve, Mt Gazey, along the river, on siliceous rocks, alt. 1900-2200 m, leg. Ö. Szatala, 03.08.1954 (BP 96051).

Ecology and distribution: on frequently wetted and irrigated siliceous rocks in subalpine to alpine rivers. Previously known only from southeastern and southern Central Alps (Thüs and Schultz 2008).

Taxonomic notes: Thelidium pertusatii is characterised by massive involucrellum, which can reach the base of the exciple. T. methorium (Nyl.) Hellb. differs only in thinner involucrellum of usually $<90 \mu \mathrm{m}$, and in the ratio of involucrellum thickness to exciple diameter, which is $<0.33$. For more information about differences and phylogeny of these two species see Thüs and NASCIMbene (2008).

In the examined specimen the form of involucrellum depends on the presence of apical depression (see Figs 2-3). Even parts measured thinner are always 
above $90 \mu \mathrm{m}$. The development of thick involucrellum is probably an adaptation to the harsh alpine environment. More studies on distribution and ecological preferences are needed.

\section{Verrucaria bulgarica Szatala}

(Figs 4-6)

Type: Bulgaria, the Rhodopes, town of Smolyan, on soft calcareous rock [“Čepelarska planina: ad viam inter Pašmakli et Rajkovo; supra saxa calc.”], alt. ca 1000 m, leg. Ö. Szatala, 05.06 .1929 (holotype: BP 34105!, isotype: BP 3!).

Thallus epilithic, thin or up to $140 \mu \mathrm{m}$ thick, minutely areolate, dark brown; areoles $180-350 \mu \mathrm{m}$ in diameter, plane to slightly convex, fertile areoles larger than sterile areoles; uppermost layer with brown pigment; black basal layer absent. Perithecia $100-170 \mu \mathrm{m}$ in diameter, prominent or semi-immersed in the centre of areoles, black, not covered by thallus, one per areole. Involucrellum 15-35 $\mu \mathrm{m}$ thick, hemispherical or conical, appressed to exciple and reaching the base-level. Exciple colourless to pale brown. Asci not observed. Ascospores 10-12 $\times 7-8 \mu \mathrm{m}$, simple, broadly ellipsoid, colourless, without perispore. Conidiomata not observed.

Ecology and distribution: a terrestrial species growing over calcareous rocks. Reported from Bulgaria, Great Britain and the South Orkney Islands (Antarctic Ocean) (Øvstedal and Lewis Smith 2001, Orange 2013).

Taxonomic notes: in Bulgaria Verrucaria bulgarica is known only from the type locality, and there are no more records after 1930. In the protologue, the thickness of thallus is given as $0.015 \mathrm{~mm}(15 \mu \mathrm{m})$. Such kind of thin thallus can be considered as almost absent, since the measurements show that the thickness is mostly above $100 \mu \mathrm{m}$, which can also explain the formation of areoles. SzATALA (1930) gave the description of areoles, which means that the fresh materials were also with defined areoles. Reports from Great Britain and the South Orkney Islands are for thallus mainly without areoles, rarely with few cracks (ØvSTEDAL and Lewis Smith 2001, Smith et al. 2009). According to Purvis et al. (1992) areoles sometimes can be peeling, and the species may occur on quite different substrates, e.g. on damp, shaded Ulmus bark. The observed substratum in the type is friable and unstable, which is not typical for the crustose Verrucaria due to erosion, and variation in the morphology of the thallus is also possible. Molecular studies are still not available in the terrestrial lichen-forming fungi with small spores in the genus Verrucaria.

Verrucaria bulgarica is ecologically and morphologically closely related to $V$. tristis (A. Massal.) Kremp. following KRZEWICKA (2012). V. tristis differs in bigger perithecia and in the involucrellum present around the upper half of exciple. 

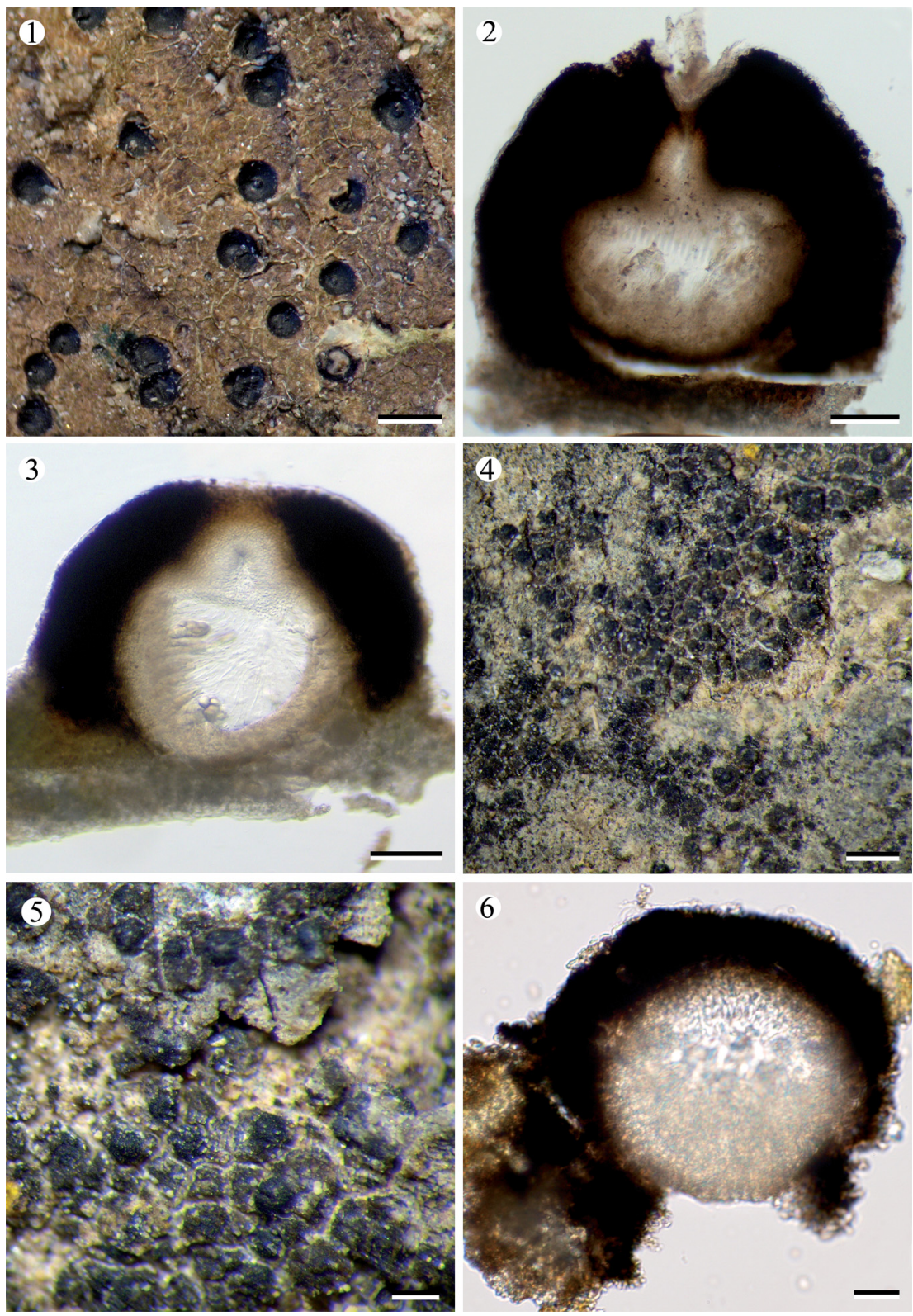

Figs 1-6. 1= Thelidium pertusatii, general habit (BP 96051) (scale = 1 mm). $2=$ Thelidium pertusatii, vertical section of perithecium with thick involucrellum and apical depression (BP 96051) $($ scale $=100 \mu \mathrm{m}) .3=$ Thelidium pertusatii, vertical section of smaller perithecium without apical depression $(\mathrm{BP})($ scale $=100 \mu \mathrm{m}) .4=$ Verrucaria bulgarica, general habit $($ BP 3) $($ scale $=0.5 \mathrm{~mm})$. $5=$ Verrucaria bulgarica, areoles and prominent perithecia $($ BP 3) $($ scale $=200 \mu \mathrm{m}) \cdot 6=$ Verrucaria bulgarica, vertical section of smaller perithecium (BP 3) $($ scale $=20 \mu \mathrm{m})$. 


\section{Verrucaria umbrinula Nyl.}

Thallus epilithic, minutely cracked-areolate to areolate, dark brown to black; areoles $200-350 \mu \mathrm{m}$ in diameter, slightly convex. Perithecia $170-250 \mu \mathrm{m}$ in diameter, semi-immersed, one per areole. Involucrellum absent. Exciple 20-30 $\mu \mathrm{m}$ thick, black throughout. Asci not observed. Ascospores 16-20 $\times 5-7 \mu \mathrm{m}$, narrowly ellipsoid, simple, colourless. Conidiomata not observed.

Specimen examined: Bulgaria, Black Sea coast, town of Burgas, hills near St. Anastasia Island, on siliceous rocks, leg. Ö. Szatala, 11.06.1929 (BP 34494).

Ecology and distribution: on siliceous and non-calcareous rocks, in open, sun-exposed places. Reported from Europe, Asia and North America (Ess LINGER and Egan 1995, Urbanavichus and ANDreev 2010, KrZEwickA 2012).

Taxonomic notes: the presence of involucrellum as separate structure is not observed. SERVÍT (1954) mentioned in the description of Verrucaria umbrinula that the involucrellum merges with exciple. The Bulgarian specimen is identical with Servít's schematic drawing (SERvít 1954: table III, fig. 37).

Verrucaria umbrinula is easily recognisable by the presence of small, narrowly ellipsoid ascospores, minutely areolate thallus and distribution on noncalcareous rocks.

Acknowledgements - We are grateful to Dr Holger Thüs (Natural History Museum, London, UK) for the confirmation of Thelidium pertusatii, and Dr Edit Farkas (Institute of Ecology and Botany, MTA ÖK, Vácrátót, Hungary) for her kind help in making microphotographs of Verrucaria bulgarica. Prof. Cvetomir Denchev (Institute of Biodiversity and Ecosystem Research, BAS, Sofia, Bulgaria) is acknowledged for his advice and help. This study was partly supported by the Synthesys project, grant HU-TAF-2782 "Taxonomic study of Verrucariaceae (lichenized fungi) in Bulgaria”.

Összefoglaló: Atanas Popnikolov és Szatala Ödön lichenológusok korábbi feldolgozatlan, továbbá Lőkös László újabb gyűjtéséből 5 Bulgáriára új, zárt termőtesttel rendelkező, kőzetlakó zuzmófajt mutattunk ki: Polyblastia cupularis, P. dermatodes, Porina lectissima, Thelidium pertusatii és Verrucaria umbrinula. Mind az öt fajt részletesen jellemezzük a Magyar Természettudományi Múzeum tulajdonában levő példányok alapján. Két, világviszonylatban is ritka fajról (Thelidium pertusatii, Verrucaria bulgarica) további illusztrációs anyagot is bemutatunk, utóbbi faj esetében, melyet Szatala Ödön írt le 1930-ban, a típuspéldányokról.

\section{REFERENCES}

EsSLINGER, T. L. and EGAN, R. S. (1995): A sixth checklist of lichen-forming, lichenicolous, and allied fungi of the continental United State and Canada. - Bryologist 98: 467-549. http://dx.doi.org/10.2307/3243586

KrzewickA, B. (2012): A revision of Verrucaria s. 1. (Verrucariaceae) in Poland. - Polish Bot. Studies 27: 3-143. 
KrZewicka, B., Stoy kov, D. Y. and Nowak, J. (2007): New and noteworthy species of Verrucaria from Bulgaria. - Mycol. Balcanica 4: 131-134.

Mayrhofer, H., Denchev, C. M., Stoykov, D. Y. and Ni kolova, S. O. (2005): Catalogue of the lichenized and lichenicolous fungi in Bulgaria. - Mycol. Balcanica 2: 3-61.

Orange, A. (2013): British and other pyrenocarpous lichens. - Department of Biodiversity and Systematic Biology, National Museum of Wales, Wales, $169 \mathrm{pp}$.

Отте, V. (2005): Noteworthy lichen records for Bulgaria. - Abh. u. Bericht. des Naturkundemus. Görlitz 77(1): 77-86.

Øvstedal, D. O. and Lewis Smith, R. I. (2001): Lichens of Antarctica and South Georgia. A guide to their identification and ecology. - Cambridge University Press, Cambridge, UK, 424 pp.

Purvis, O. W., Coppins, B. J., Hawksworth, D. L., James, P. W. and Moore, D. M. (eds) (1992): The lichen flora of Great Britain and Ireland. - Natural History Museum Publications and British Lichen Society, London, 720 pp.

Savić, S. and Tibell, L. (2012): Polyblastia in Northern Europe and the adjacent Arctic. - Symb. Bot. Upsal. 36(1): 1-69.

Savić, S., Tibell, L., Gueidan, C. and Lutzoni, F. (2008): Molecular phylogeny and systematics of Polyblastia (Verrucariaceae, Eurotiomycetes) and allied genera. - Mycol. Res. 112: 1307-1318. http://dx.doi.org/10.1016/j.mycres.2008.05.002

Servít, M. (1954): Lichenes familiae Verrucariacarum. - Československé Akademie Věd, Praha, $249 \mathrm{pp}$.

Shivarov, V. V. (2013): New records of Verrucariaceae (Ascomycota) from Bulgaria. - Mycobiota 3: 11-17. http://dx.doi.org/10.12664/mycobiota.2013.03.02

Shivarov, V. V. and Stoy коv, D. Y. (2013): New records of pyrenocarpous lichenized fungi from Bulgaria. - Mycotaxon 121: 133-138. http://dx.doi.org/10.5248/121.133

Smith, C. W., Aptroot, A., Coppins, B. J., Fletcher, A., Gilbert, O. L., James, P. W. and Wolseley, P. A. (eds) (2009): The lichen flora of Great Britain and Ireland. 2nd ed. - The British Lichen Society, London, 1046 pp.

SPIER, L., VAN DorT, K. and Fritz, Ö. (2008): A contribution to the lichen mycota of old beech forests in Bulgaria. - Mycol. Balcanica 5: 141-146.

Swinscow, T. D. V. (1971): Pyrenocarpous lichens: 15. Key to Polyblastia Massal. in The British Isles. - Lichenologist 5: 92-113. http://dx.doi.org/10.1017/s0024282971000124

Szatala, Ö. (1929): Beiträge zur Flechtenflora von Bulgarien. I. - Magyar Bot. Lapok 28: 82-99.

Szatala, Ö. (1930): Beiträge zur Flechtenflora von Bulgarien II. - Magyar Bot. Lapok 29: 58-104.

Thüs, H. and NAscimbene, J. (2008): Contributions toward a new taxonomy of Central European freshwater species of the lichen genus Thelidium (Verrucariales, Ascomycota). - Lichenologist 40: 499-521. http://dx.doi.org/10.1017/S0024282908007603

Thüs, H. and Schultz, M. (2008): Freshwater flora of Central Europe. Vol. 21/1, Fungi, Part 1, Lichenes. - Spektrum, Heidelberg, $224 \mathrm{pp}$.

Urbanavichus, G. and Andreev, M. (2010): A checklist of lichen flora of Russia. - Nauka, St Petersburg, $194 \mathrm{pp}$.

VoNDRÁK, J. (2006): Contribution to the lichenicolous fungi in Bulgaria. I. - Mycol. Balcanica 3: $7-11$.

Wirth, V. (1995): Die Flechten Baden-Württembergs. 1-2. - E. Ulmer, Stuttgart.

ZsCHACKe, H. (1933): Epigloeaceae, Verrucariaceae und Dermatocarpaceae. - In: ZAHLBRUCKNER, A. (ed.): Dr. L. Rabenhorst's Kryptogamen-Flora von Deutschland, Österreich und der Schweiz. Band 9. Akademische Verlagsgesellschaft M. B. H., Leipzig, pp. 44-480.

(submitted: 05.09.2015, accepted: 04.11.2015) 